\title{
The Ethical Obligation to Disrupt: Facing the Bloody City in Nah 3:1-7
}

\section{Juliana ClaAssens (University of Stellenbosch)}

\begin{abstract}
In Nah 3:1, the Assyrian capital Nineveh is called "city of bloodshed." Nineveh is indeed "a bloody city," filled with the blood of the numerous dead bodies associated with the fall of the city. However, as also in the case of a similar portrayal of the city of Jerusalem in Ezek 22:2, Nineveh is depicted as a female entity, hence suggesting that one may also read these poetic texts as invoking the image of a bleeding, menstruating city with all the connotations of not only ritual impurity but also moral guilt associated with this portrayal of sexual perversion or pollution (cf. Lev 18:19; 20:18). In this regard, it is significant that Nineveh in Nah 3:4 is called " $a$ whore" - a derogatory slur that often is used to denote those who are "other" or foreign. The article will explore the ethical implications of disruption as a reading strategy that is particularly important when reading the prophetic traditions through the lens of gender, postcolonial and queer biblical interpretation.
\end{abstract}

KEYWORDS: Nah 3, Ezek 22, Feminist biblical interpretation, Disgust, Sexual Pollution, Sexual Perversion, Gender-based Violence

\section{A INTRODUCTION}

\author{
Ah! City of bloodshed, \\ utterly deceitful, full of booty-- \\ no end to the plunder! (Nah 3:1) \\ You, mortal, will you judge, \\ will you judge the bloody city? \\ Then declare to it all its abominable deeds (Ezek 22:2)
}

Feminist scholars have long noted the virulent language of sexual violence that is used in the prophetic discourse to denote the downfall of a besieged city and her inhabitants. Whether it be Personified Jerusalem (Lam 1-2; Jer 13:22), Daughter Babylon (Isa 47:1-13; Jer 51:1-10) or the Whore Nineveh (Nah 3:17) who is on the receiving end of the devastating violence of military warfare, the commonalities associated with this evocative metaphor are clear. The threat

* Submitted: 19/07/2021; peer-reviewed: 12/11/2021; accepted: 17/11/2021. L. Juliana Claassens, "The Ethical Obligation to Disrupt: Facing the Bloody City in Nahum 3:1-7," Old Testament Essays 34 no. 3 (2021): 835 - 848. DOI: https://doi.org/10.17159/2312-3621/2021/v34n3a10. 
or the reality of the city's destruction, the penetration of its defences, the ravaging of its innermost sanctuary, all are encapsulated in the metaphor of a violated, weeping humiliated female body. ${ }^{2}$ However, beyond the troubling appropriation of sexual violence in the prophetic discourse, which is not only used to capture Judah's own sense of self before, amidst and after military invasion, but which also extends to enemy cities as an integral part of Judah's coming to terms with trauma, ${ }^{3}$ a whole range of layers, connotations and implications associated with this particular prophetic metaphor is in need of further scrutiny.

With special reference to the portrayal of Nineveh as "city of bloodshed," which also may be translated as "bloody city" in Nah 3:1, this article employs a reading strategy that may be characterised as a disruptive reading. In conversation with the works of scholars such as Eva Feinstein on sexual pollution and Elizabeth Goldstein on impurity and gender in the Hebrew Bible, this article considers the way in which the language of sexual perversion or pollution has informed the metaphor of the city as an adulterous woman or a prostitute that is described in Ezek 22:2 as "the bloody city" or "city of bloodshed." According to Feinstein, Ezekiel's condemnation of the "bloody city" is closely associated with laws detailing perversion, pollution or abomination in Lev 18 and 20 that also include the law prohibiting sexual relations with a menstruating woman (Lev 18:19; 20:18). This article proposes that a disruptive reading pertaining to the layers, connotations and implications of the way in which perversion and disgust are understood in these biblical traditions also may inform our understanding of yet another "city of bloodshed," as the downfall of Nineveh,

2 Brad E. Kelle, "Wartime Rhetoric: Prophetic Metaphorization of Cities as Female," in Writing and Reading War: Rhetoric, Gender, and Ethics in Biblical and Modern Contexts (ed. Brad E. Kelle and Frank R. Ames; SBLSymS 42; Atlanta, GA: SBL Press, 2008), 95-112; Pamela Gordon and Harold C. Washington, "Rape as a Military Metaphor in the Hebrew Bible," in A Feminist Companion to the Latter Prophets (ed. Athalya Brenner; Sheffield: Sheffield Academic Press, 1995), 308-325.

${ }^{3}$ Kathleen O'Connor, Jeremiah: Pain and Promise (Minneapolis: Fortress, 2011), 4758; Christopher G. Frechette, "Daughter Babylon Raped and Bereaved (Isaiah 47): Symbolic Violence and Meaning-making in Recovery from Trauma," in Bible through the Lens of Trauma (ed. Elizabeth Boase and Christopher G. Frechette; Semeia Studies 86; Atlanta: SBL Press, 2016), 67-83; Elizabeth Boase, "The Traumatized Body: Communal Trauma and Somatization in Lamentations," in Trauma and Traumatization in Individual and Collective Dimensions: Insights from Biblical Studies and Beyond (ed. Eve-Marie Becker, Jan Dochhorn and Else Holt; Göttingen: Vandenhoeck \& Ruprecht, 2014), 193-209.

4 Eva Levavi Feinstein, Sexual Pollution in the Hebrew Bible (Oxford: Oxford University Press, 2014), 136-141. Cf. also Elizabeth Wayne Goldstein, "Impurity and Gender in the Hebrew Bible: Ideological Intersections in the Books of Leviticus, Ezekiel and Ezra," PhD dissertation, University of California, San Diego, 2010), 89116. 
Israel's much-revered enemy, is celebrated in Nah 3:1ff. ${ }^{5}$ I propose that such a disruptive reading strategy not only holds important ethical implications for the way in which we approach prophetic metaphor but also informs our individual and collective attempts to counter the ongoing effects of gendered and racial stereotypes which have done so much damage in our respective communities.

\section{B LAYERS}

The assumptions and worldviews underlying the portrayal of sexual violence in the prophetic discourse come from somewhere. Eva Feinstein's work on sexual pollution in the Hebrew Bible offers a fascinating account of the legacy of the laws in Lev 18 and 20 concerning perversions (or what she calls pollution) in two texts, namely, Ezek 22 and Ezra 9. Drawing on the work by Elizabeth Goldstein on impurity and gender in Leviticus, Ezekiel and Ezra, Feinstein identifies a number of close parallels between the portrayal of the "bloody city" in Ezek 22:2 and the laws in Lev 18 and 20 that dictate a range of mostly sexual behaviours that is classified as "perverse" (Lev 18:23) or "abominable" (Lev $18: 22,27,29,30) .{ }^{6}$ These behaviours have the effect of polluting, defiling or contaminating the body, both individually and collectively. ${ }^{7}$ These chapters include, among others, laws outlawing incest (Lev 18:7, 9; 20:17) ${ }^{8}$ and bestiality (Lev $18: 23 ; 20: 15-16$ ), in addition to texts that typically have been weaponised in terms of the conversation on homosexuality (Lev 18:22; 20:13). Probably most unexpectedly however, amid this list of sexual actions that is considered to be perverse is the law against drawing near to a woman while she is menstruating (Lev 18:19; 20:18).

In Lev 15:24, typically taken to be part of the priestly traditions $(\mathrm{P})$, sexual relations with a menstruating woman are not prohibited, but rather stipulate the

5 Feinstein notes that "the expression "bloody city" (ער דמים) also occurs in Nah 3:13 where it is used to describe the capital city of Assyria, Nineveh. Feinstein argues that Nahum's description of Nineveh focuses more on literal bloodshed, Sexual Pollution, 247. However, as I will argue in this article, the other connotations associated with "bloody city" identified above, may also be applicable in the case of Nahum's rendition of the city of bloodshed.

6 Feinstein outlines the various terms that are used interchangeably to classify the response to the said behaviour including "abominate" (געל), "abhor" (שקץ), "revile" (תעב), which all communicate a sense of loathing with the overt directive to reject or shun what is considered to be perverse or abominable, Sexual Pollution, 7, 20.

7 Feinstein, Sexual Pollution, 130. Feinstein, Sexual Pollution, 5, 7, distinguishes between what was considered inherently impure and what had the ability to contaminate or pollute.

8 One finds in Lev 18 and 20 a number of different laws against uncovering the nakedness of a range of individuals (mothers, sisters, fathers, aunts, uncles, daughtersin-law, grandchildren), with the exception of what Feinstein terms "The Missing Daughter of Leviticus 18 and 20." In this appendix, Feinstein, Sexual Pollution, 170173 , considers the various possibilities for this particular omission. 
period the male partner is considered to be unclean. In Lev 18 and 20 that form part of what is known as the Holiness Code $(\mathrm{H})$, a distinct change occurs, though, when sex with a menstruating woman is clearly forbidden. ${ }^{9}$ Whereas in Lev $18: 19$, sex with a menstruating woman is prohibited because it makes one impure, in Lev 20:18 having sex with a menstruating woman has become a moral issue - in Tarja Philip' words, "a defiling sin with irreversible results" that is considered on par with incest, bestiality and child sacrifices to Molech. ${ }^{10}$

In the book of Ezekiel, this connection between impurity, immorality and gender is even more pronounced when the figure of a menstruating woman comes to represent the sins of the people of Judah. Both Feinstein and Goldstein show how Ezekiel draws upon some of the ideas found particularly in H. ${ }^{11}$ However, as evident in the figure of the bloody city (עיר הדמים) in Ezek 22:2 (cf. also Ezek 24:6,9), the female blood that in the priestly tradition was considered inherently unclean with the potential to defile or pollute, in Ezekiel, inadvertently, is connected to immorality. ${ }^{12}$

Goldstein makes a compelling case for three interwoven interpretative possibilities associated with the city of bloodshed that draw upon three different meanings of דמים to capture this movement from impurity to immorality. First, the reference to Jerusalem as a bloody city may, on the one hand, refer to the abundance of spilt blood of those killed, thus, denoting the acts of violence as well as the violation in her midst. ${ }^{13}$ However, given the fact that this city, as also other cities in the ancient Near East, quite distinctly is portrayed in female terms, the reference to her blood being in her midst (Ezek 24:7) may in the second instance also refer to menstruation, as Jerusalem is depicted as a woman who bleeds. ${ }^{14}$ In the third instance, the reference to the city of bloodshed may be understood in terms of the bloodguilt Jerusalem had incurred because of the crimes committed within her walls. ${ }^{15}$

9 Tarja S. Philip, "Gender Matters: Priestly Writing on Impurity," in Embroidered Garments: Priests and Gender in Biblical Israel (ed. Deborah W. Rooke; Sheffield: Sheffield Phoenix Press, 2009), 50.

10 Philip, "Gender Matters," 52.

11 Feinstein, Sexual Pollution, 130-136; Goldstein, "Impurity and Gender," 89-116.

12 Goldstein, "Impurity and Gender," 100; Feinstein, Sexual Pollution, 136. Feinstein, Sexual Pollution, 131, continues: "As we will see, the book of Ezekiel does not adopt Leviticus 18's application of sexual pollution language to men, but it utilizes Leviticus 18 's ideas about the relationship between purity and retention of the land to explain the impending Babylonian exile. It also expands Leviticus 18's conception of sexual pollution into a broader conception of moral pollution that leads to exile, although sexual pollution remains a key component of this moral pollution."

13 Goldstein, "Impurity and Gender," 101-102.

14 Ibid., 106-107; Feinstein, Sexual Pollution, 136.

15 Goldstein, "Impurity and Gender," 110; Feinstein, Sexual Pollution, 136. Cf. also Steven Tuell, Ezekiel (NIBCOT 10; Grand Rapids: Baker Books, 2009), 144-145, that 
Merging these three meanings, one could say that it is because the blood of those murdered within her walls is exposed, calling from the ground much as the blood of Abel that cried out to God in Gen 4:10, that God is stepping forward to avenge the bloodguilt that is associated with this city of bloodshed. ${ }^{16}$ Moreover, the writer of Ezekiel is super-imposing the image of the bloody woman and the bloody city by intentionally confusing moral impurity with ritual impurity. As Goldstein argues, "By linking menstrual blood with bloodguilt, the prophet is explicit in his condemnation of female blood." 17 This line of interpretation is also evident elsewhere in Ezekiel in which a connection is made between the people worshipping other gods, depicted in terms of the metaphor of an adulterous woman or a prostitute as the people defile the land "with their ways and their deeds" (Ezek 36:17). As God pronounces in Ezek 36:17, "[T]heir conduct in my sight was like the uncleanness of a woman in her menstrual period" (הָנְָדָה) ${ }^{18}$ Indeed as Goldstein puts it, "the bleeding woman [has become] the symbol for everything that is wrong with Israel."19

In these texts, the notion of bloodguilt is connected to a range of immoral, or, in Ezekiel's mind, "abhorrent" (22:14) behaviours that go back to the legal traditions of the Holiness Code [cf., for example, defiling oneself by worshipping other idols (22:2-4); oppressing the widow (22:7); spilling innocent blood (22:18); profaning the Sabbath (22:8); committing incest (22:10-11); having sexual intercourse with a menstruating woman (22:10)]. Menstrual blood, which in the priestly traditions, was considered "a small, involuntary ritual defilement" thus has been turned into something so negative and shameful, that it represents all of the sins of Israel that is great enough to cause the eviction of the people

points to the human rights violations at the heart of this indictment when "the mistreatment of society's most vulnerable persons by Jerusalem's royalty" is considered to be "contemptible." As Tuell argues, "they have oppressed the alien and mistreated the fatherless and the widow (v. 7)."

16 Goldstein, "Impurity and Gender," 111.

17 Ibid., 102.

18 Cf. also Tarja Philip, "Gender Matters," 54-55, who argues that "the use of the noun נדח in the book of Ezekiel is an indicator of a change of attitude towards the impurity of menstruation. Once prohibition of menstrual sex had singled out the impurity of menstruation as something distinct from other impurities, menstruation itself became more closely connected to the concept of impurity. The basic meaning of נדח is 'menstruation', but then it came to denote the menstrual impurity and the menstruant herself, and impurity in general."

19 Goldstein, "Impurity and Gender," 102. 
from the land. ${ }^{20}$ Divine violence and exile becomes thus, according to Feinstein, both "a just punishment" as well as "an act of purification" (Ezek 22:3-16). ${ }^{21}$

\section{CONNOTATIONS}

How then did a bodily function shared by all women around the world and from the beginning of time - one that transcends ethnicity, class, sexual orientation and age, become such a despised phenomenon with the propensity to be viewed as something perverse on the same level as incest and bestiality?

In the first instance, it is important to note that in many cultures and times, menstruation is viewed with contempt as something dirty or, in stronger terms, abhorrent or revolting. Mary Douglas in her seminal work on purity and danger speaks about pollution in terms of "dirt [as] matter out of place."22 Analogously, one could say that menstruation may be viewed as "blood out of place" and together with other body fluids, specifically associated with sexual organs, exhibit the innate ability to contaminate individuals who come into contact with it. $^{23}$

On an evolutionary level, Feinstein demonstrates how disgust could have functioned as a type of protective measure, for example, in terms of contaminated food that could be considered harmful. ${ }^{24}$ However, one finds as well that disgust inevitably also extends to individuals who are deemed outsiders to the community and hence posing a real or, more often, a perceived threat. In what Martha Nussbaum describes as "misogynistic disgust," women, as the ultimate other, are scorned or reviled because of the fear of female sexuality and a heightened aversion of female emissions - something which is epitomised in the deeply engrained connection between menstruation and disgust. ${ }^{25}$

20 Goldstein, "Impurity and Gender," 112. Feinstein, Sexual Pollution, 140 argues as follow: "The people's sins pollute the land on which they "sit" like a menstruating woman's blood." She continues that whereas Ezekiel does not employ the notion of "the land spewing out its inhabitants," the prophet rather maintains that "God removed the people from the land because they contaminated it."

21 Feinstein, Sexual Pollution, 136. Cf. also the discussion by Tuell, Ezekiel, 92-93, with reference to Ezek 16:35-43.

22 Feinstein, Sexual Pollution, 23.

23 Ibid., 24. Cf. also Eve Levavi Feinstein, "Sexual Pollution in the Hebrew Bible: A New Perspective," in Bodies, Embodiment, and Theology of the Hebrew Bible (ed. S. Tamar Kamionkowski and Wonil Kim; LHBOTS 465; New York: T\&T Clark, 2010), 114-145 (127).

24 Feinstein, Sexual Pollution, 27. Feinstein notes that "[f]ood, specifically from animal sources, is the source of dietary pollution, and certain animals-specifically when dead - .... body products, specifically those associated with the sexual organs.... [and] contact with corpses is powerfully polluting," 24 .

25 Feinstein, Sexual Pollution, 36. 
A wealth of examples in popular culture attests to what Lauren Rosewarne describes as "The Menstrual Mess: Disgust, Horror, and the Fear of Menstruation." In her fascinating account of the manifold ways in which the topic of menstruation features in books, films and television, Rosewarne cites a scene from the film To Sir With Love (1967) in which the teacher, played by Sidney Poitier, refers to a sanitary product burnt by the kids in class as "a disgusting object." He furthermore reprimands the responsible student by saying, "A decent woman keeps certain things private. Only a filthy slut would have done this!" 26

An additional moral dimension that draws a connection between disgust and distrust is furthermore evident in the popular expression, "I just don't trust anything that bleeds for five days and doesn't die," as voiced by the character, Mr. Garrison, in the film South Park: Bigger, Longer and Uncut (1999). Rosewarne argues that this quote, as also the other variations of this quote elsewhere in popular culture [Keith (Michael Rooker) in Keys to Tulsa (1996), and Chad (Aaron Eckhart) in In the Company of Men (1997)] "boasts the same misogynist undercurrent rendering the menstruator as abject and presenting menstruation as something not only abhorrent but potentially non-human."27 Often described as "the Curse of Eve," menstruation moreover expresses the ideal that women are masters of deceptions, as evident also in the concealment of menstruation. Given the very long history of "the idea of women-of female sexuality — as being evil_or at least instigating evil consequences" that goes back to the biblical story of Eve, according to Rosenwarne, it is not surprising that "on-screen portrayals of periods frequently reference long-standing misogynist ideas about one of the most female biological functions." 28

It is precisely this deeply engrained connection between menstruation and disgust in popular culture, with its deep roots in the Judeo-Christian traditions, that helps us in making sense of the laws concerning sex with a menstruating woman in the Holiness Code in Leviticus. Feinstein clearly shows how the author of Lev 18 seeks to persuade his audience of the wrongness of a number of mostly sexual actions by employing a strong connection between disgust and pollution language and imagery. By calling the sexual actions prohibited in these chapters, also including sex with a menstruating woman "abominable" (Lev 18:22, 27, 29, 30) and "perverse" (v. 23), the land is depicted as having a visceral reaction, literally vomiting out its inhabitants (Lev 18:24-28). Feinstein describes this rhetorical strategy in the following way:

26 Lauren Rosewarne, Periods in Pop Culture: Menstruation in Film and Television (Lanham: Lexington Books, 2012).

27 Rosewarne, Periods in Pop Culture.

28 Ibid. 
[This] appeal to disgust makes the 'wrongness' of these acts seem self-evident, and by including broadly accepted taboos alongside more controversial restrictions, the text encourages the audience to extend an existing repugnance toward certain relationships to a broader range of behaviors. ${ }^{29}$

Moreover, in texts concerning the "bloody city" in the book of Ezekiel, this connection between disgust and the menstruating woman is even more pronounced. For instance, in Ezek 24:6, the reference to the bloody city is directly connected to disgust when the prophet, in a sign act, is commanded to create a bloody mixture of putrid animal flesh and bones with a layer of rust (or pot scum translated by Goldstein as "filth") in an [iron] cooking pot to symbolise the blood of the city. ${ }^{30}$ This revolting combination is a good example of how the multiple levels of the meaning of blood associated with the female city are considered repulsive. In Ezek 23:45, a connection is furthermore drawn between the adulterous woman and the triple understanding of blood on their hands, which may, as outlined in the previous section, conceivably refer to bloodshed, bloodguilt as well as menstruation. ${ }^{31}$ Assumptions of a woman being an unfaithful, deceptive adulteress or an immoral prostitute are hence conflated with the emotion of disgust that has come to be associated with menstruation, therefore, generating as Goldstein contends, "a new conceptualization of women and the female body" according to which "their menstruating bodies can become the symbol of sin, and the symbol of leading others into sin through unholy intercourse." 32 Moreover, as evident in the examples of the metaphors of sexual violence in the prophetic discourse cited at the beginning of this article, a logical next step would be to view the invasion and violent destruction of the female cities as their rightfully deserved punishment - the "she asked for it!" response so many victims of sexual and domestic violence have had to endure. ${ }^{33}$

29 Feinstein, Sexual Pollution, 130.

30 Goldstein, "Impurity and Gender," 102.

31 Ibid., 110.

32 Ibid., 89.

33 Daniel L. Smith-Christopher, "Ezekiel in Abu Ghraib: Rereading Ezekiel 16:37-39 in the Context of Imperial Conquest," in Ezekiel's Hierarchical World: Wrestling with a Tiered Reality (ed. Stephen L. Cook and Corrine L. Patton; SBL Symposium Series 31; Atlanta: SBL, 2004), 141-144, offers a comprehensive overview of the works of feminist interpreters that have identified the deeply problematic rhetoric underlying the metaphor of God as a scorned, abusive spouse, and the city wife as a promiscuous, adulterous woman in his compelling essay. Smith-Christopher, "Ezekiel in Abu Ghraib," 153-155, makes a good point though when he argues that the male elite audience of Ezekiel, due to the effects of the military invasion and exile by the hand of the Babylonian army, very much feels like a violated/humiliated woman and, hence, in a classic case of self-blaming that is a common coping strategy in communities under duress, blame themselves in order to make sense of what had happened to them. 


\section{IMPLICATIONS}

So what are the implications of this exercise in delving through the layers and connotations associated with the image of the "bloody city" in Ezek 22:2 (cf. also Ezek 24:6, 9) for reading the depiction of Nineveh as city of bloodshed in Nah 3:1ff?

First, I proposed in this article that the depiction of Nineveh as the "bloody city" in Nah 3:1 might be enhanced by exploring the layers and connotations of the occurrence of a similar portrayal of the city of Jerusalem in Ezek 22:2 that has been the topic of inquiry in this article. ${ }^{34}$ In this regard, the multiple layers associated with the city of bloodshed in Ezek 22:2 (24:6, 9), may be helpful for our understanding of Nah 3:1ff. Nineveh is indeed "a bloody city," filled with the blood of the numerous dead bodies associated with the fall of the city. The blood of those killed is expounded by invoking vivid images of corpses that are left unburied that are described as a "multitude of slain, masses of corpses, and no end to dead bodies." 35

Moreover, in light of the fact that Nineveh had been responsible for great bloodshed suggests also that the reference to the bloody city may refer as well to the bloodguilt associated with the history of violence attributed to this capital city of the Assyrian Empire - the fall of Nineveh being celebrated by the author of Nahum as her just reward for all she had done to Israel. ${ }^{36}$ Though one may also consider that, as Laurel Lanner rightly observes, the notion of bloodguilt, as elsewhere in the prophetic discourse, does not only pertain to acts of military warfare but also to those instance in which those in a position of power and privilege engaged in social justice violations. ${ }^{37}$

In addition, as also in the case of the city of Jerusalem, Nineveh is depicted as a female entity, suggesting, as in the case of Ezek 22:2, that one may

34 Cf. Lanner's argument with reference to the Oracles against the Nations, that links between Nahum and the Book of the Twelve has not sufficiently been explored, Laurel Lanner, Who Will Lament Her? The Feminine and the Fantastic in the Book of Nahum (LHBOS 434; T\&T Clark, 2006), 35. One also could make a similar case in terms of Nahum's connection with the Major Prophets.

35 Feinstein, "Sexual Pollution," 126, argues that in many cultures, "menstrual blood, human corpses, certain animal species," especially if they are dead, "are considered inherently and invariably so."

36 Cf. Steed Vernyl Davidson's argument regarding "the imperializing discourse of vengeance that enlists national outrage for excesses perpetrated by other nations," "Postcolonial Readings of the Prophets," in The Oxford Handbook of the Prophets (ed. Carolyn Sharp; Oxford: Oxford University Press, 2016), 507-526 (520).

37 Lanner, Who Will Lament Her?, 141. Cf. also the reference to the city being "full of plunder, never without booty" in Wilhelm J. Wessels, "Cultural Sensitive Readings of Nahum 3:1-7," HTS Teologiese Studies/ Theological Studies 74/1 (2018): 4931. https://doi.org/10.4102/hts.v74i1.4931. 
read this text as invoking the image of a bleeding, menstruating city with all the connotations of not only ritual impurity but also moral guilt associated with this depiction of sexual perversion or pollution. In this regard, it is significant that Nineveh is quite vividly depicted in this text as a whore - a derogatory slur that often is used to denote those other than themselves. ${ }^{38}$ In addition, to "the countless debaucheries of the prostitute" (Nah 3:4) in which Nineveh is said to engage, she is also called "the mistress of sorcery" - a twofold reference that, according to Klaas Spronk, represents two aspects of "evil power," that is, harlotry as the ability to seduce others and sorcery as enforcing her will upon others with her, what the text describes as, "gracefully alluring" feminine wiles. ${ }^{39}$

In conversation with the layers and connotations associated with the bloody city in Ezek 22:2 $(24: 6,9)$ outlined in this article, the portrayal of the bloody city in Nah 3 is furthermore permeated with disgust. This is evident in the grisly scene of unburied corpses, clearly signifying ritual pollution, which forms the backdrop of this portrayal of the city of bloodshed. The multiple levels of meaning associated with the bloody city, which conceivably include associations with menstrual blood, clearly convey a sense of disgust or revulsion with regard to the fallen city. Indeed, the bloody city has become the subject of great scorn as God's contempt for Nineveh is manifested in God's act of throwing "filth" or "excrement" at her (Nah 3:6). ${ }^{40}$ In conjunction also with the metaphorical depiction of a prostitute or sorceress that features prominently in this text, there is a general sense of pollution or one may say perversion associated with the portrayal of this capital city of one of Israel's most dreaded foes. ${ }^{41}$

Second, the fact that menstruation has come to represent a moral category in Ezek 22 also extends to the occurrence of this metaphor in Nah 3. The depiction of a bloody city, with all the associations outlined regarding a menstruating woman and its connotations with disgust and sin, serves as a means

38 Lanner, Who Will Lament Her?, 24. Julia M. O'Brien argues that: "Nahum, having inherited the tradition of personifying cities as women, uses the culture's definition of the worst kind of woman, the whore, as a slur by which to demean Nineveh," Nahum (2nd ed.; Sheffield: Sheffield Phoenix Press, 2009), 61. Cf. also Wilda C. M. Gafney, Nahum, Habakkuk, Zephaniah (Wisdom Commentary Series; Collegeville: Liturgical Press, 2017), 49.

39 Klaas Spronk, Nahum (Kampen: Kok Pharos, 1997), 121-122. Cf. also Lanner, Who Will Lament Her?, 143.

40 Yvonne Sherwood, “Tongue-Lashing” or a Prophetic Aesthetics of Violation: An Analysis of Prophetic Structures that Reverberate Beyond the Biblical World," in Aesthetics of Violence in the Prophets (ed. Chris Franke and Julia M. O'Brien; Sheffield: T\&T Clark, 2010), 88.

41 Sherwood, "Tongue-Lashing," 88. 
to justify violence. ${ }^{42}$ Whereas in Ezekiel, the intertwined notions of immorality and disgust are encapsulated in the figure of a revolting, menstruating woman with violence following in its wake, in Nahum, a whole added layer of revulsion is added when Nineveh, the capital city of the much-feared enemy empire, is not just the female other but also the enemy female other. Reading from a postcolonial perspective, Steed Davidson shows how imperialist discourse, which is deeply masculinist in nature, typically employs "sexually and religiously deviant forms of the core representations of women." 43 One furthermore has to be mindful of how the other is constructed in prophetic discourse, even and perhaps especially, the enemy other. Carolyn Sharp warns us to be extremely vigilant when it comes to the "virulent language of military despoliation and the sexual shaming of enemies" one finds in Jeremiah but even more so in the book of Nahum. ${ }^{44}$ Language that propagates the dehumanisation of enemy others, which furthermore employs female bodies to conjure up the strongest form of disgust is just plain dangerous especially in today's volatile geopolitical climate. A compelling example is found in the thought-provoking essay by Daniel Smith-Christopher on reading "Ezekiel in Abu Ghraib," shortly after US soldiers engaged in dehumanising practices of their prisoners. SmithChristopher writes:

Abu Ghraib, like Sand Creek, My Lai, and Hiroshima and Nagasaki, reveals instead that militarism only reduces us to a disturbing immoral similarity to the ancient empires who conquered the biblical Hebrews. We resemble our enemies. ${ }^{45}$

\section{E CONCLUSION}

In this article, we have seen how the formulation of the "bloody city" in Nah 3:1 as well as its parallel portrayal of the city of Jerusalem in Ezek 22:2 appears to be deeply rooted in the legal traditions in Leviticus, specifically, pertaining to the Holiness Code's prohibition of sex with a menstruating woman. It was argued

42 Lanner remarks that in Hos 2 and Ezek 16, violence is employed "as a punishment for a wife who goes whoring. Yet, in Nahum the metaphor applies to one who has not been considered YHWH's wife," Who Will Lament Her?, 149. Cf. also the conversation on the metaphor of rape and sexual violence in this text, Wessels, "Cultural Sensitive Readings"; O'Brien, Nahum, 60-63; Gafney, Nahum, Habakkuk, Zephaniah, 50-54.

43 Davidson, "Postcolonial Readings," 518-519. Cf. also Gafney, Nahum, Habakkuk, Zephaniah, 49, who argues that, "the characterization of Nineveh as a whore is rooted in misogyny and xenophobia. Nineveh, personified as a woman, is a whore because she is foreign; all non-Israelite women are treated with suspicion if not outright hostility in the Hebrew Bible."

44 Carolyn J. Sharp, "Buying Land in the Text of Jeremiah: Feminist Commentary, the Kristevan Abject, and Jeremiah 32," in Prophecy and Power: Jeremiah in Feminist and Postcolonial Perspective (ed. Christl M. Maier and Carolyn J. Sharp; LHBOTS 577; London: Bloomsbury T\&T Clark, 2013), 152.

45 Smith-Christopher, "Ezekiel," 141. 
that prophetic rhetoric's application of the legal traditions and the original laws in the Holiness tradition go back to some deep-seated connotations between disgust and menstruation as well as assumptions about sexuality and gender, both in the biblical traditions as well as in popular culture.

I propose that to read the prophetic traditions through the lens of gender, postcolonial and queer biblical interpretation constitutes a central aspect of disruption as a reading strategy that in this article was used to investigate the layers, connotations and implications of a prophetic image such as the bloody city in Nah 3:1 (cf. Ezek 22:2). The reason such a reading strategy is so important is that, if the association of perversion with the female (foreign) body, generating disgust and repulsion are left to stand, it may soon lead to violence when what is considered abhorrent is to be expunged. In this regard, in her exposé on the legacy of biblical violence, Yvonne Sherwood highlights the dangers of prophetic rhetoric that so blatantly employs "violence... in the exposed human bodies - at the level of symbol" which she argues also "extend[s] into the violence of form." As she argues:

Force is embodied in the performance of an absolutely sovereign and absolutely irrevocable/irresistible discourse: iteration, reiteration; the voice without limits, speaking and acting as if there were no other voices/bodies or counterforces in the world." 46

Perhaps this is the real danger lurking in the priests' and the prophets' formulations of metaphors and laws that are deeply rooted in layers upon layers of negative gendered and sexual stereotypes. Indeed, constituting "voice[s] without limits," these laws and prophetic rhetoric speak and act "as if there were no other voices/bodies or counterforces in the world." ${ }^{47}$ In a disruptive reading that considers the layers, connotations and implications associated with this particular prophetic metaphor in Nah 3 as well as Ezek 22, we find that "the bloody city" talks back, thereby, disrupting the harmful stereotypes and constructions associated with female bodies that are used to denigrate our worst enemies.

\section{F BIBLIOGRAPHY}

Boase, Elizabeth. "The Traumatized Body: Communal Trauma and Somatization in Lamentations." Pages 193-209 in Trauma and Traumatization in Individual and Collective Dimensions: Insights from Biblical Studies and Beyond. Edited by Eve-Marie Becker, Jan Dochhorn and Else Holt. Göttingen: Vandenhoeck \& Ruprecht, 2014. https://doi.org/10.13109/9783666536168.177.

Davidson, Steed Vernyl. "Postcolonial Readings of the Prophets." Pages 507-526 in The Oxford Handbook of the Prophets. Edited by Carolyn Sharp. Oxford: Oxford University Press, 2016.

46 Sherwood, "Tongue-Lashing," 99.

47 Ibid. 
Feinstein, Eve Levavi. "Sexual Pollution in the Hebrew Bible: A New Perspective." Pages 114-145 in Bodies, Embodiment, and Theology of the Hebrew Bible. Edited by S. Tamar Kamionkowski and Wonil Kim. LHBOTS 465. New York: T\&T Clark, 2010.

. Sexual Pollution in the Hebrew Bible. Oxford: Oxford University Press 2014.

Frechette, Christopher G. "Daughter Babylon Raped and Bereaved (Isaiah 47): Symbolic Violence and Meaning-making in Recovery from Trauma." Pages 67-83 in Bible through the Lens of Trauma. Edited by Elizabeth Boase \& Christopher G. Frechette. Semeia Studies 86. Atlanta: SBL Press, 2016.

Gafney, Wilda C.M. Nahum, Habakkuk, Zephaniah. Wisdom Commentary Series. Collegeville: Liturgical Press, 2017.

Goldstein, Elizabeth Wayne. "Impurity and Gender in the Hebrew Bible: Ideological Intersections in the Books of Leviticus, Ezekiel and Ezra." PhD dissertation, University of California, San Diego, 2010.

Gordon, Pamela and Washington, Harold C. "Rape as a Military Metaphor in the Hebrew Bible." Pages 308-325 in A Feminist Companion to the Latter Prophets. Edited by Athalya Brenner. Sheffield: Sheffield Academic Press, 1995.

Kelle, Brad E. "Wartime Rhetoric: Prophetic Metaphorization of Cities as Female." Pages 95-111 in Writing and Reading War: Rhetoric, Gender, and Ethics in Biblical and Modern Contexts. Edited by Brad E. Kelle/Frank Ritchel Ames. SBLSymS 42. Atlanta: SBL Press, 2008.

Lanner, Laurel. Who Will Lament Her? The Feminine and the Fantastic in the Book of Nahum. LHBOS 434. T\&T Clark, 2006).

O’Brien, Julia M. Nahum. 2nd ed. Sheffield: Sheffield Phoenix Press, 2009.

O'Connor, Kathleen M. Jeremiah: Pain and Promise. Minneapolis: Fortress, 2011. https://doi.org/10.2307/j.ctt22nm847.

Philip, Tarja S. "Gender Matters: Priestly Writing on Impurity." Pages 40-59 in Embroidered Garments: Priests and Gender in Biblical Israel. Edited by Deborah W. Rooke. Sheffield: Sheffield Phoenix Press, 2009.

Rosewarne, Lauren. Periods in Pop Culture: Menstruation in Film and Television. Lanham: Lexington Books, 2012.

Sharp, Carolyn J. "Buying Land in the Text of Jeremiah: Feminist Commentary, the Kristevan Abject, and Jeremiah 32." Pages 150-172 in Prophecy and Power: Jeremiah in Feminist and Postcolonial Perspective. Edited by Christl M. Maier and Carolyn J. Sharp. LHBOTS 577. London: Bloomsbury T \&T Clark, 2013.

Sherwood, Yvonne. "“Tongue-Lashing' or a Prophetic Aesthetics of Violation: An Analysis of Prophetic Structures that Echo Beyond the Biblical World." Pages 88-111 in The Aesthetics of Violence in the Prophets. Edited by Julia M. O'Brien and Chris Franke. The Library of Hebrew Bible/Old Testament Studies. London: T\&T Clark, 2010.

Smith-Christopher, Daniel L. "Ezekiel in Abu Ghraib: Rereading Ezekiel 16:37-39 in the Context of Imperial Conquest." Pages 141-158 in Ezekiel's Hierarchical World: Wrestling with a Tiered Reality. Edited by Stephen L. Cook and Corrine L. Patton. SBL Symposium Series 31. Atlanta: SBL, 2004.

Spronk, Klaas. Nahum. Kampen: Kok Pharos, 1997.

Tuell, Steven. Ezekiel. Old Testament Series New International Biblical Commentary 10. Grand Rapids: Baker Books, 2009. 
Prof L. Juliana Claassens, University of Stellenbosch, Faculty of Theology of Old Testament, Head of Gender Unit, Email: jclaassens@sun.ac.za; ORCID: 0000-0002-5490-0974 